\title{
Birinci ve Son Sınıf Hemşirelik Öğrencilerinde Eleştirel Düşünme ve Etkileyen Faktörler
}

\author{
First and Last Grade Nursing Students' Levels of Critical Thinking and \\ Affecting Factors \\ Şebnem BILLGIÇa Zeynep KURTULUŞ TOSUN ${ }^{\mathbf{b}}$
}

\begin{abstract}
ÖZET Amaç: Bu araştırma, birinci ve son sınıf hemşirelik öğrencilerinin eleştirel düşünme düzeylerini ve eleştirel düşünmeyi etkileyen faktörleri belirlemek amacıyla gerçekleştirilmiştir. Yöntem: Tanımlayıcı tipte olan araştırma bir üniversitenin Sağlik Yüksekokulu Hemşirelik Bölümü’nde gerçekleştirilmiş̧ir. Araştırma 20132014 eğitim-öğretim yılı bahar döneminde, eleştirel düşünme düzeylerinde en fazla fark olabileceği düşünülen birinci ve son sınıf öğrencileri ile yürütülmüştür. Birinci ve son sınıftaki toplam 210 öğrenciden araştırmaya katılmayı kabul eden 160'ı araştırmada yer almıştır. Veriler Kişisel Bilgi Formu ve Kaliforniya Eleştirel Düşünme Eğilimleri Ölçeği (KEDEÖ) kullanılarak toplanmıştır. Veriler tanımlayıcı (ortalama, standart sapma, yüzdelik hesapları) ve karşılaştırmalı (Mann Whitney U testi, Kruskal Wallis) istatistiksel araştırma testleri kullanılarak analiz edilmiştir. Bulgular: Hemşirelik öğrencilerinin eleştirel düşünme puan ortalaması $252.50 \pm 28.96$ olarak bulunmuştur. Öğrencilerin KEDEÖ alt boyut puan ortalamaları arasında en yüksek puanı analitik düşünce alt boyutundan (46.03 \pm 7.13$)$, en düşük puanı ise doğruyu arama alt boyutundan (37.36 \pm 6.90$)$ aldığı belirlenmiş̧tir. Araştırmada öğrencinin devam ettiği sınıfın, mezun olduğu okulun, anne eğitiminin, gelir düzeyinin ve aile yapısının öğrencilerin eleştirel düşünme düzeylerini etkilediği saptanmıştır. Sonuç: Eleştirel düşünme düzeyleri orta düzeyde bulunan hemşirelik öğrencilerinin öğrenimleri süresince eleştirel düşünme becerilerini geliştirecek şekilde desteklenmesi gerekmektedir. Öğrencilerin derse aktif katıldı̆̆ı öğrenme ortamlarının oluşturulması, nitelikli soru ve sorgulamalarının desteklenerek gerekli yönlendirmelerin yapılması ile eleştirel düşüncenin geliştirilmesine destek olunması önemlidir.
\end{abstract}

Anahtar Kelimeler: Eleştirel düşünme, hemşirelik eğitimi, hemşirelik öğrencileri

\begin{abstract}
Aim: This study was conducted to determine the level of critical thinking and the factors affecting critical thinking of the first and last grade nursing students. Method: This descriptive study, School of Health of Nursing Department was carried out at a state university. This study was carried out with first and last grade students that might have the most different levels of critical thinking in 2013-2014 academic years' spring semester. A total of 210 students from 160 of the first and the last grade students who accepted to participate in the study. Data of research was collected by using Personal Information Form and California Critical Thinking Disposition Inventory (CCTDI). The data were analyzed using by descriptive (mean, standard deviation, percentage) and comparative statistical tests (Mann-Whitney U Test and Kruskal Wallis Test). Results: The mean score of critical thinking of nursing students is calculated 252.50 \pm 28.96 , CCTDI subscale scores between the highest mean scores of students from analytical thinking subscale $(46.03 \pm 7.13)$, while the lowest score from the right call subscale (37.36 \pm 6.90$)$ was determined. Students in the class of continued, the school graduation of students', mother's education, income level and family structure has been found to affect the level of critical thinking of students'. Conclusion: Moderate levels of critical thinking in nursing students during their education must be supported to develop critical thinking skills. İt is important that active learning environment be established, necessary guidance be made by supporting qualified inquiries and interrogation, and the development of critical thinking be supported.
\end{abstract}

Key Words: Critical thinking, nursing education, nursing students

Geliş Tarihi/Received: 2015-11-13/ Kabul Tarihi/Accepted: 2016-01-14

${ }^{a}$ Araş. Gör. Dr. Namık Kemal Üniversitesi Sağlık Yüksekokulu Namık Kemal Mah. Kampüs Cad. No: 159030 TEKİRDAĞ. Mail: sbilgic@nku.edu.tr Tel: 02822503115.

${ }^{\text {b} Y r d . ~ D o c ̧ . ~ D r . ~ N a m ı k ~ K e m a l ~ U ̈ n i v e r s i t e s i ~ S a g ̆ l ı k ~ Y u ̈ k s e k o k u l u ~ N a m ı k ~ K e m a l ~ M a h . ~ K a m p u ̈ s ~ C a d . ~ N o: 1 ~} 59030$ TEKİRDAĞ. Mail: ztosun@nku.edu.tr Tel:0 2822503107

Sorumlu Yazar Adres/ Correspondence: Şebnem Bilgiç, Mail: sbilgic@nku.edu.tr. Namık Kemal Üniversitesi Sağlık Yüksekokulu Namık Kemal Mah. Kampüs Cad. No: 159030 TEKİRDAĞ.

Atıf: Bilgiç Ş, Kurtuluş Tosun Z. Birinci ve Son Sınıf Hemşirelik Öğrencilerinde Eleştirel Düşünme ve Etkileyen Faktörler. HSP 2016;3(1):39-47.

To cite this article: Bilgiç Ş, Kurtuluş Tosun Z. First and Last Grade Nursing Students' Levels of Critical Thinking and Affecting Factors. HSP 2016;3(1):39-47. 


\section{GIIRIŞ}

Bilgilerin analizi, sentezi ve değerlendirilmesi süreci olarak kabul edilen eleştirel düşünme; her yönlü düşünmeyi bazen de karşıt düşünmeyi gerektiren, aktif, etkin, örgütlü ve işlevsel bir süreçtir. ${ }^{1-3}$ Değişen toplumlar, toplumsal dinamikler, sağlık bakım gereksinimleri ve sağlık politikaları ile modern bir meslek haline gelen, doğası gereği sürekli problem çözme ve profesyonel kararlar alma durumunda olan hemşireliğin literatürüne eleştirel düşünme ilk kez 1980'lerde girmesine rağmen, kavramsal açıklaması 1990 yılına kadar yapılamamıştır. ${ }^{4-6}$ Bireyin yaşam kalitesini ve hemşirelik bakımının kalitesini etkileyen eleştirel düşünme günümüzde giderek önem kazanan bir kavramdır. Eleștirel düşünmenin kazanılması için bireyin mesleki karar verme ve farklı biçimlerde düşünme becerileri ile hemşirelik bilgisinde belirli bir birikiminin olması gerekmektedir. ${ }^{7}$

Toplumun sağlığını koruma, geliştirme ve yaşam kalitesini artırma yönünde etkin ve kaliteli hizmet verebilme; meslekte profesyonellik, otonomi ve güç sahibi olma iyi düzeyde eleştirel düşünme becerisine sahip olma ile gerçekleşir. ${ }^{8,9}$ Teknolojik gelişmelerin ve kanıta dayalı uygulamaların hızla arttığı sağlık bakım ortamında, birden fazla seçenek arasında uygun ve doğru olanı en hızlı biçimde seçmek durumunda kalan hemşirelerin, sorgulama yapma, akıl yürütme, bilgiyi işleme, bireyselleştirilmiş bakım verme, problem çözme yeteneği kazanma ve etkili iletişim kurabilmeleri için eleştirel düşünceye sahip olması gereklidir. ${ }^{10-13} \mathrm{Bu}$ bağlamda bir beceriden çok kişilik özelliği olan, zihinsel yeteneğin önemli bir boyutunu oluşturan, olgunlaşma ve yaşantı zenginliklerinden etkilenen eleştirel düşüncenin hemşirelik öğrencilerinde geliştirilmesi önem kazanmaktadır. Ülkemizde yapilan araştırmalarda hemşirelik öğrencilerinde eleştirel düşüncenin düşük ya da orta düzeyde olduğu belirtilmektedir. ${ }^{5,9,14}$ Eleştirel düşünme puanı yüksek olan hemşirelik öğrencilerinin akademik ve klinik yönden daha başarılı oldukları gösterilmiştir. ${ }^{5} \mathrm{Bu}$ çerçevede gelecekte etkin hizmet verebilecek hemşireler yetiştirebilmek için hemşirelik eğitimi boyunca öğrencilerin eleştirel düşünce becerilerinin geliştirilmesi önem kazanmaktadır. ${ }^{9}$

\section{Amaç}

$\mathrm{Bu}$ araştırma, birinci ve son sınıf hemşirelik öğrencilerinin eleştirel düşünme düzeylerini ve eleştirel düşünmeyi etkileyen faktörleri belirlemek amacıyla gerçekleştirilmiştir.

\section{YÖNTEM}

\section{Araştırmanın Evren ve Örneklemi}

Tanımlayıcı nitelikteki araştırmanın evrenini bir üniversitenin Sağlık Yüksekokulu Hemşirelik bölümünde, 2013-2014 eğitimöğretim yılı bahar döneminde öğrenimlerini sürdüren birinci ve dördüncü sınıf öğrencileri (210 öğrenci) oluşturmuştur. $\mathrm{Bu}$ öğrenciler arasından, verilerin toplandığ gün okulda bulunan ve araştırmaya katılmayı kabul eden 96 birinci sınıf, 64 dördüncü sinıf öğrencisi olmak üzere toplam 160 öğrenci araştırmada yer almıştır. Eleştirel düşünme düzeylerinde en fazla fark olabileceği düşünülen birinci ve son sınıf öğrencileri çalışmaya alınmıştır.

\section{Veri Toplama Araçları}

Araştırmada veri toplama aracı olarak ilgili literatür doğrultusunda hazırlanan ve öğrencilerin demografik özelliklerini içeren Kişisel Bilgi Formu ve Kalifornia Eleştirel Düşünme Eğilimleri Ölçeği (KEDEÖ) kullanılmıştır.

\section{Kaliforniya Eleştirel Düşünme Eğilimleri Ölçeği (KEDEÖ)}

Giancarlo (1990-1998) tarafindan geliştirilen ve Kökdemir (2003) tarafindan geçerlilik ve güvenilirliği yapılmış olan ölçeğin Cronbach's Alpha katsayıs1 0.88 olarak bulunmuştur. Altı1ı likert tipte olan ölçek 51 maddeden oluşmaktadır. Ölçeğin kuramsal olarak belirlenmiş ve psikometrik olarak da test edilmiş doğruyu arama (7 madde), açık fikirlilik (12 madde), analitik düşünce (10 madde), sistematiklik (6 madde), kendine güven ( 7 madde), meraklılık (9 madde) olmak üzere altı alt boyutu bulunmaktadır. Ölçekte her madde için verilen puan esas alınmaktadır. Olumsuz maddeler $(5,6,9,11,15,18,19,20$, $21,22,23,25,27,28,33,36,41,43,45,47$, $49,50)$ ters yönde puan almaktadır. Her bir alt ölçekten elde edilen ham puanlar soru sayısına bölündükten sonra 10 ile çarpılarak en düşük 6 ve en yüksek 60 değerini alan bir standart puana çevrilmiştir. Bütün alt ölçeklerde olas1 
en düşük ve en yüksek değerler sabittir. KEDEÖ toplamından alınan 240'ın altındaki puan "düşük", 240-300 arasındaki puan "orta" ve 300'ün üzerindeki puan "yüksek eleştirel düşünme beceri düzeyi” olarak kabul edilmektedir.,14-16 Araştırmamızda ölçeğin Cronbach's Alpha katsayısı 0.87 olarak bulunmuştur.

\section{Araştırmanın Etik Yönü}

Araştırma verileri, Namık Kemal Üniversitesi Tıp Fakültesi Etik Kurulundan etik onay, araştırmanın yürütüleceği kurumdan yazılı izin alındıktan sonra elde edilmiştir. Öğrencilerden araştırmanın amac1, kendilerinden ne beklenildiği, yasal hakları ve elde edilen bilgilerin gizli tutulacağı konusunda bilgilendirme yapılarak sözel izin alınmıştır.

\section{Verileri Analizi}

Araştırma verilerinin istatistiksel analizi, bilgisayar ortaminda SPSS 16.0 (Statistical Package for the Social Sciences) paket programı ile tanımlayıcı (yüzdelik, aritmetik ortalama, standart sapma ve minimummaksimum) testler ve karşılaştırmalı istatistik yöntemler (Mann Whitney U Testi, Kruskall Wallis Testi) kullanılarak yapılmıştır.

\section{BULGULAR}

\section{Öğrencilerin Tanıtıcı Özelliklerine İlişkin Bulgular}

Yaş ortalamas1 $20.95 \pm 2.43$ y1l olan ögrencilerin sosyodemografik özellikleri ve ailelerine ilişkin diğer tanıtıcı özellikleri Tablo 1 'de gösterilmiştir.

Öğrencilerin \%41.2'si genel lise mezunu olup, birinci sinıf öğrencilerin $\% 42.70$ 'i anadolu lisesi, dördüncü sinıf ögrencilerin ise \%45.3'ü genel lise mezunudur.

Öğrencilerin KEDEÖ Toplam ve Alt Boyut Puanları

Araştırmaya katılan öğrencilerin KEDEÖ toplamından ve alt boyutlarından aldıkları ortalama puanlar Tablo 2'de gösterilmiştir. Öğrencilerin KEDEÖ'den aldıkları toplam puan ortalaması $252.50 \pm 28.96$ olup, en yüksek puan ortalamasını analitik düşünce, en düşük puan ortalamasını ise doğruyu arama alt boyutundan aldıkları belirlenmiştir (Tablo 2).
Tablo 1. Öğrencilerin tanıtıcı özelliklerinin dağılımı

\begin{tabular}{llll}
\hline Özellik & Değişken & n & \% \\
\hline Cinsiyet & Kadın & 127 & 79.4 \\
& Erkek & 33 & 20.6 \\
\hline Sınıf & 1.sınıf & 96 & 60.0 \\
& 4.sınıf & 64 & 40.0 \\
\hline Mezun Olunan & SML* & 14 & 8.8 \\
Okul & Genel lise & 66 & 41.2 \\
& Anadolu lisesi & 65 & 40.6 \\
& Diğer & 15 & 9.4 \\
\hline Anne eğitimi & Okur- yazar değil & 14 & 8.7 \\
& Okur yazar & 7 & 4.4 \\
& İlköğretim & 107 & 66.9 \\
& Lise ve üzeri & 32 & 20.0 \\
\hline Gelir düzeyi & Düşük & 16 & 10.0 \\
& Orta & 141 & 88.1 \\
& Yüksek & 3 & 1.9 \\
\hline Üniversite & Çok iyi & 23 & 14.4 \\
başarısı & İyi & 71 & 44.4 \\
& Orta & 59 & 36.8 \\
& Başarısız & 7 & 4.4 \\
\hline Aile yapısı & Çekirdek aile & 132 & 82.5 \\
& Geniş aile & 24 & 15.0 \\
& Parçalanmış aile & 4 & 2.5 \\
\hline Aile tutumu & Otoriter ve & 10 & 6.2 \\
& redddedici & & 7.5 \\
& Hoşgörülü & 12 & 15.0 \\
& Koruyucu & 24 & 6.2 \\
& Tutarsız & 10 & 65.0 \\
& Demokratik & 104 & \\
\hline
\end{tabular}

*Sağlık Meslek Lisesi

Tablo 2. Öğrencilerin KEDEÖ toplam ve alt boyut puan ortalamaları

\begin{tabular}{|c|c|c|}
\hline & Dağılım Aralığı & Ortalama $\pm S S$ \\
\hline $\begin{array}{l}\text { Doğruyu } \\
\text { Arama }\end{array}$ & $20.0-55.7$ & $37.36 \pm 6.90$ \\
\hline Açık Fikir & $21.7-55.8$ & $40.23 \pm 7.60$ \\
\hline $\begin{array}{l}\text { Analitik } \\
\text { Düşünce }\end{array}$ & $18.0-60.0$ & $46.03 \pm 7.13$ \\
\hline Sistematiklik & $25.0-60.0$ & $43.87 \pm 8.21$ \\
\hline $\begin{array}{l}\text { Kendine } \\
\text { Güven }\end{array}$ & $17.1-60.0$ & $41.35 \pm 7.56$ \\
\hline Meraklılık & $14.4-60.0$ & $43.67 \pm 8.06$ \\
\hline $\begin{array}{l}\text { KEDEÖ } \\
\text { Toplam }\end{array}$ & 168.0-325.6 & $252.50 \pm 28.96$ \\
\hline
\end{tabular}




\section{Öğrencilerin Eleştirel Düşüncelerini Etkileyen Faktörlere İlişkin Bulgular}

Öğrencilerin demografik ve aile özelliklerine göre KEDEÖ toplam ve alt boyutlarına ait puan ortalamalarının dağılımı Tablo 3'de verilmiştir.

Öğrencilerin

demografik

özelliklerinden öğrenim gördükleri sınıfa göre analitik düşünce alt boyutu puan ortalamaları arasında, mezun olduğu okula göre doğruyu arama alt boyutu puan ortalamaları arasında istatistiksel olarak önemli farklılık bulunmuştur $(\mathrm{p}<0.05)$, (Tablo 3$)$.

Annelerin eğitim düzeyine göre öğrencilerin açık fikirlilik, analitik düşünce, kendine güven, meraklılık alt boyutları ve KEDEÖ toplam ölçek puan ortalamaları arasında istatistiksel olarak önemli farklılıklar saptanmıştır $(p<0.05)$, (Tablo 3$)$. Anne eğitimi lise ve üzeri olan öğrencilerin yukarıda söz edilen alt boyut ve KEDEÖ toplam puan ortalamasından en yüksek puanı aldığı görülmüştür (Tablo 3).

Öğrencilerin gelir düzeyine göre KEDEÖ toplam puanı ve alt boyut puan ortalamaları arasında farklılık olup olmadığ karşılaştırıldığında, gelir düzeyine göre açık fikirlilik, analitik düşünce, meraklılık alt boyut puanları ve KEDEÖ toplam puanı arasında istatistiksel olarak önemli farkl1l1k bulundu $(\mathrm{p}<0.05)$. Gelir düzeyini 'düşük' olarak tanımlayan öğrencilerin KEDEÖ toplam ve açık fikirlilik, analitik düşünce, meraklılık alt boyutlarından daha yüksek puan aldığ 1 saptanmıştır $(\mathrm{p}<0.05)$, (Tablo 3).

Aile yapısına göre kendine güven, meraklılık alt boyutları ve KEDEÖ toplam puanı arasında anlamlı fark bulunmuştur $(p<0.05)$. Parçalanmış aile yapısına sahip öğrencilerin diğer öğrencilere göre daha yüksek, geniş aile yapısına sahip öğrencilerin en düşük puanı aldığı belirlenmiştir (Tablo 3).

Öğrencilerin cinsiyeti, üniversite başarısını algılamaları ve aile tutumlarına göre KEDEÖ toplam puan ve alt boyut puanlarının ortalamaları arasında istatistiksel olarak önemli fark saptanmamıştır ( $\mathrm{p}>0.05)$, (Tablo 3).

\section{TARTIŞMA}

Genetik faktörler yanında bireyin yetiştiği ortam ve aldığ $\breve{1}_{1}$ eğitim gibi çevresel faktörlerden de etkilenen eleştirel düşünme becerisi, hemşirenin klinik alanda alternatifler bulmasını, problem çözmesini, otonomi sağlamasını, profesyonelliğini sürdürmesini, hemşirelik bilgi ve becerisini sistematik bir şekilde hasta bakımına yansıtmasını olanaklı kıldığ 1 için klinik başarıyı artırmaktadır. ${ }^{17} \mathrm{Bu}$ nedenle eleştirel düşünme becerisinin desteklenmesi önemlidir.

Araştırma kapsamına alınan öğrencilerin KEDEÖ puan ortalamasının orta düzeyde olduğu saptanmıştır (252.95 \pm 29.11$)$. Hemşire ve hemşirelik öğrencileri ile bugüne kadar yapılan çalışmalarda da eleştirel düşünme düzeylerinin genellikle düşük ve orta düzeyde olduğu saptanmıştır. .,9-10,14,17-20 $^{-1}$ Hemşirelerde eleştirel düşünme düzeyinin yüksek bulunduğu araştırma sonuçlarına ise ülke dişında yürütülen araştırmalarda rastlanmıştır. ${ }^{21,22}$

KEDEÖ'nün alt boyutları incelendiğinde; en yüksek ortalamanın 46.03 \pm 7.13 puan ile analitik düşünce, en düşük ortalamanın ise $37.36 \pm 6.90$ puan ile doğruyu arama alt boyutlarına ait olduğu saptanmıştır. Özdelikara ve ark.'nın (2012) hemşirelik öğrencileri ile Certel ve ark.'nın (2011) beden eğitimi öğretmenliği öğrencileri ile yaptı̆̆ 1 araştırmaların sonuçları da mevcut araştırma ile benzerlik göstermektedir.

KEDEÖ toplam puan ortalamaları k1z öğrencilerde erkek öğrencilere göre daha yüksek olsa da, fark istatistiksel olarak önemli bulunmamıştır. Özdemir'in (2005) üniversite öğrencilerinin eleştirel düşünme becerilerini incelediği araştırmasında da, araştırmamıza benzer şekilde, cinsiyetin eleştirel düşünceyi etkilemediği belirtilmiștir.

Araștırmamızda ilk ve son sınıf öğrencileri arasında, birinci sınıfta daha yüksek olan "analitik düşünce" alt boyut puan ortalaması dışında, KEDEÖ toplam ve alt boyut puan ortalamaları farklı değildi. Hemşirelik bölümlerine sayısal puan türü ile öğrenci alınması, birinci sınıfta Anadolu lisesi mezunlarının dördüncü sınıfa göre daha fazla olması analitik düşünme alt boyut puan ortalamasının birinci sinıfta daha yüksek olmasının nedeni olarak düşünülebilir. Şenturan ve Alpar'1n (2008) birinci ve son sınıf öğrencisi toplam 2029 öğrenci ile yaptıkları araştırmalarında da araştırmamıza 
Tablo 3. Öğrencilerin tanıtıcı özelliklerine göre KEDEÖ ve alt boyut puanları ile ilişkili faktörler

\begin{tabular}{|c|c|c|c|c|c|c|c|c|}
\hline \multicolumn{2}{|c|}{ Tanıtıcı Özellikler } & $\begin{array}{c}\text { Doğruyu Arama } \\
36,15 \pm 6,28\end{array}$ & \begin{tabular}{|l} 
Açık Fikir \\
$38.48 \pm 8.56$
\end{tabular} & $\begin{array}{c}\text { Analitik Düşünce } \\
46.12 \pm 8.15\end{array}$ & $\begin{array}{c}\text { Sistematiklik } \\
46,57 \pm 10,35\end{array}$ & $\begin{array}{c}\text { Kendine Güven } \\
41,21 \pm 7,69 \\
\end{array}$ & \begin{tabular}{|l|} 
Meraklılık \\
$45,35 \pm 8,08$
\end{tabular} & \begin{tabular}{|c|} 
KEDEÖ Toplam \\
$253.88 \pm 31,46$
\end{tabular} \\
\hline Cinsiyet & $\begin{array}{l}\text { Kiz } \\
\text { Erkek }\end{array}$ & $\begin{array}{c}36,15 \pm 6,28 \\
37,67 \pm 7,04 \\
p>0.05\end{array}$ & $\begin{array}{c}38.48 \pm 8.56 \\
40,68 \pm 7,30 \\
p>0.05\end{array}$ & $\begin{array}{c}46.12 \pm 8.15 \\
46.00 \pm 6.87 \\
p>0.05\end{array}$ & $\begin{array}{c}46,57 \pm 10,35 \\
43,16 \pm 7,45 \\
p>0.05\end{array}$ & $\begin{array}{c}41,21 \pm 7,69 \\
41,40 \pm 7,56 \\
\mathrm{p}>0.05 \\
\end{array}$ & $\begin{array}{c}45,35 \pm 8,08 \\
43,24 \pm 8,03 \\
p>0.05\end{array}$ & $\begin{array}{c}253.88 \pm 31,46 \\
252.15 \pm 28.40 \\
p>0.05\end{array}$ \\
\hline Sinıf & $\begin{array}{l}\text { 1.Sinif } \\
4 . \sin 1 f\end{array}$ & $\begin{array}{c}36,59 \pm 6,77 \\
38,50 \pm 7,00 \\
p>0.05\end{array}$ & $\begin{array}{c}40,40 \pm 7,25 \\
39.97 \pm 8,15 \\
p>0.05\end{array}$ & $\begin{array}{c}47.05 \pm 7.07 \\
44.48 \pm 6.99 \\
\mathbf{p}<\mathbf{0 . 0 5}\end{array}$ & $\begin{array}{c}44,46 \pm 8,89 \\
42,97 \pm 7,06 \\
\mathrm{p}>0.05\end{array}$ & $\begin{array}{c}41,93 \pm 7,76 \\
40,49 \pm 7,23 \\
\mathrm{p}>0.05\end{array}$ & $\begin{array}{c}44,12 \pm 8,32 \\
43,00 \pm 7,66 \\
p>0.05\end{array}$ & $\begin{array}{c}254,56 \pm 28,34 \\
249,43 \pm 29,83 \\
p>0.05\end{array}$ \\
\hline Mezun Olunan Okul & $\begin{array}{l}\text { SML } \\
\text { Genel Lise } \\
\text { Anadolu Lisesi } \\
\text { Diğer }\end{array}$ & $\begin{array}{c}34,80 \pm 9,49 \\
36,39 \pm 6,04 \\
39,38 \pm 6,90 \\
35,24 \pm 6,00 \\
\mathbf{p}<\mathbf{0 . 0 5}\end{array}$ & $\begin{array}{c}41,49 \pm 9,33 \\
38,83 \pm 7,54 \\
41,41 \pm 7,34 \\
40.11 \pm 6,90 \\
\mathrm{p}>0.05\end{array}$ & $\begin{array}{c}47.57 \pm 8.80 \\
45.55 \pm 6.42 \\
46.54 \pm 7.44 \\
44.47 \pm 7.20 \\
p>0.05\end{array}$ & $\begin{array}{c}40,24 \pm 8,44 \\
43,61 \pm 7,41 \\
44,31 \pm 7,51 \\
46,44 \pm 12,90 \\
p>0.05\end{array}$ & $\begin{array}{c}43,78 \pm 5,70 \\
40,80 \pm 7,80 \\
42,15 \pm 7,50 \\
38,10 \pm 7,57 \\
\mathrm{p}>0.05\end{array}$ & $\begin{array}{c}46.67 \pm 6,21 \\
43,75 \pm 7,08 \\
43,86 \pm 8,62 \\
39,70 \pm 10,14 \\
p>0.05\end{array}$ & $\begin{array}{c}254.54 \pm 30,66 \\
248.92 \pm 25.55 \\
257.65 \pm 31,29 \\
244.06 \pm 29,73 \\
\text { p }>0.05\end{array}$ \\
\hline Anne eğitimi & $\begin{array}{l}\text { Okur- yazar değil } \\
\text { Okur yazar } \\
\text { İlköğretim } \\
\text { Lise ve üzeri }\end{array}$ & $\begin{array}{c}35,71 \pm 8,02 \\
36,12 \pm 6,94 \\
37,23 \pm 6,78 \\
38,75 \pm 6,87 \\
p>0.05\end{array}$ & $\begin{array}{c}38,87 \pm 7,02 \\
33,21 \pm 10,27 \\
40,10 \pm 7,20 \\
42,79 \pm 7,69 \\
\mathbf{p}<\mathbf{0 . 0 5}\end{array}$ & $\begin{array}{c}41,00 \pm 10,34 \\
41,43 \pm 5,65 \\
46,33 \pm 6,59 \\
48,21 \pm 6,28 \\
\mathbf{p}<\mathbf{0 . 0 5}\end{array}$ & $\begin{array}{c}45,12 \pm 13,80 \\
38,57 \pm 8,13 \\
43,45 \pm 7,36 \\
45,83 \pm 7,51 \\
p>0.05\end{array}$ & $\begin{array}{c}37,65 \pm 8,73 \\
44,29 \pm 8,94 \\
40,73 \pm 7,50 \\
44,38 \pm 5,87 \\
\mathbf{p}<\mathbf{0 . 0 5}\end{array}$ & $\begin{array}{c}38,81 \pm 10,42 \\
44,60 \pm 6,74 \\
43,25 \pm 7,78 \\
47,01 \pm 6,96 \\
\mathbf{p}<\mathbf{0 . 0 5}\end{array}$ & $\begin{array}{c}237,17 \pm 35,36 \\
251,11 \pm 27,15 \\
251,11 \pm 27,15 \\
266,97 \pm 28,17 \\
\mathbf{p}<\mathbf{0 . 0 5}\end{array}$ \\
\hline Gelir düzeyi & $\begin{array}{l}\text { Düşük } \\
\text { Orta } \\
\text { Yüksek }\end{array}$ & $\begin{array}{c}37,95 \pm 6,62 \\
37,32 \pm 6,93 \\
35,71 \pm 9,37 \\
p>0.05\end{array}$ & $\begin{array}{c}45.00 \pm 7,44 \\
39,68 \pm 7,49 \\
40,55 \pm 6,25 \\
\mathbf{p}<\mathbf{0 . 0 5}\end{array}$ & $\begin{array}{c}49.50 \pm 7.83 \\
45.74 \pm 6.99 \\
41.00 \pm 3.60 \\
\mathbf{p}<\mathbf{0 . 0 5} \\
\end{array}$ & $\begin{array}{c}46,15 \pm 9,54 \\
43,69 \pm 8,08 \\
39,44 \pm 5,85 \\
\mathrm{p}>0.05\end{array}$ & $\begin{array}{c}43.31 \pm 9,15 \\
41,21 \pm 7,41 \\
38,10 \pm 4,59 \\
p>0.05\end{array}$ & $\begin{array}{c}49.38 \pm 8,42 \\
43,01 \pm 7.84 \\
44,44 \pm 5.55 \\
\mathbf{p}<\mathbf{0 . 0 5}\end{array}$ & $\begin{array}{c}271.27 \pm 35,98 \\
250,66 \pm 27,49 \\
239.25 \pm 27,93 \\
\mathbf{p}<\mathbf{0 . 0 5}\end{array}$ \\
\hline $\begin{array}{l}\text { Üniversite başarısı } \\
\text { algısı }\end{array}$ & $\begin{array}{l}\text { Çok iyi } \\
\text { İyi } \\
\text { Orta } \\
\text { Başarısız }\end{array}$ & $\begin{array}{c}38,45 \pm 5,66 \\
37,06 \pm 7,64 \\
37,46 \pm 6,63 \\
35,92 \pm 5,56 \\
\text { p }>0.05\end{array}$ & $\begin{array}{c}40,83 \pm 7,01 \\
39,34 \pm 7,34 \\
41,06 \pm 8,09 \\
40,24 \pm 8,52 \\
\mathrm{p}>0.05\end{array}$ & $\begin{array}{c}44.82 \pm 9.80 \\
46.88 \pm 6.92 \\
45.69 \pm 5.86 \\
44.00 \pm 9.00 \\
p>0.05\end{array}$ & $\begin{array}{c}45,29 \pm 7,70 \\
43,77 \pm 7,19 \\
44,01 \pm 9,33 \\
38,81 \pm 9,36 \\
p>0.05\end{array}$ & $\begin{array}{c}41,55 \pm 9,43 \\
41,95 \pm 7,26 \\
40,85 \pm 6,65 \\
38,98 \pm 11,53 \\
p>0.05\end{array}$ & $\begin{array}{c}44,93 \pm 9,88 \\
44,30 \pm 7.83 \\
42,50 \pm 7,64 \\
43,02 \pm 7,66 \\
\mathrm{p}>0.05\end{array}$ & $\begin{array}{c}255.88 \pm 36.01 \\
253,33 \pm 26,38 \\
251.58 \pm 26.37 \\
240.96 \pm 43,71 \\
p>0.05\end{array}$ \\
\hline Aile yapısı & $\begin{array}{l}\text { Çekirdek aile } \\
\text { Geniş aile } \\
\text { Parçalanmış aile }\end{array}$ & $\begin{array}{c}37,61 \pm 6,86 \\
35,83 \pm 7,55 \\
38,21 \pm 3,17 \\
p>0.05\end{array}$ & $\begin{array}{c}40,86 \pm 7,52 \\
36,63 \pm 7,73 \\
40,83 \pm 4,03 \\
\mathrm{p}>0.05\end{array}$ & $\begin{array}{c}46.08 \pm 6.93 \\
44.71 \pm 8.16 \\
52.00 \pm 4.24 \\
\mathrm{p}>0.05\end{array}$ & $\begin{array}{c}44,00 \pm 7,49 \\
42,99 \pm 12,00 \\
44,58 \pm 3,70 \\
p>0.05\end{array}$ & $\begin{array}{c}41,32 \pm 7,65 \\
40,30 \pm 7,05 \\
48,93 \pm 2,14 \\
\mathbf{p}<\mathbf{0 . 0 5}\end{array}$ & $\begin{array}{c}43,65 \pm 8,121 \\
42,22 \pm 7,35 \\
53,06 \pm 3.55 \\
\mathbf{p}<\mathbf{0 . 0 5}\end{array}$ & $\begin{array}{c}253,07 \pm 29,38 \\
242,68 \pm 25,74 \\
277,62 \pm 6,05 \\
\mathbf{p}<\mathbf{0 . 0 5}\end{array}$ \\
\hline Aile tutumu & $\begin{array}{l}\text { Otoriter ve reddedici } \\
\text { Hoşgörülü } \\
\text { Koruyucu } \\
\text { Tutarsız } \\
\text { Demokratik }\end{array}$ & $\begin{array}{c}38,29 \pm 5,67 \\
36,31 \pm 9,94 \\
36,43 \pm 7,17 \\
35,57 \pm 7,39 \\
37,77 \pm 6,56 \\
\mathrm{p}>0.05\end{array}$ & $\begin{array}{c}41,25 \pm 7,26 \\
38,06 \pm 9,47 \\
39,48 \pm 8,09 \\
39,92 \pm 8,57 \\
40.58 \pm 7,29 \\
\mathrm{p}>0.05\end{array}$ & $\begin{array}{c}43.50 \pm 9.94 \\
43.83 \pm 9.57 \\
45.83 \pm 6.86 \\
47.50 \pm 7.32 \\
46.42 \pm 6.69 \\
p>0.05\end{array}$ & $\begin{array}{c}42,83 \pm 8,43 \\
43,75 \pm 10,22 \\
46,94 \pm 10,39 \\
42,67 \pm 7,34 \\
43,38 \pm 7,44 \\
p>0.05\end{array}$ & $\begin{array}{c}37,71 \pm 8,36 \\
41,07 \pm 8,68 \\
42,38 \pm 8,02 \\
40,86 \pm 6,32 \\
41,55 \pm 7,39 \\
\mathrm{p}>0.05\end{array}$ & $\begin{array}{c}42,00 \pm 9,87 \\
42,31 \pm 9,41 \\
45,69 \pm 7,31 \\
43,89 \pm 8,20 \\
43,50 \pm 7,94 \\
\mathrm{p}>0.05\end{array}$ & $\begin{array}{c}245.28 \pm 36,26 \\
245,33 \pm 35,96 \\
256.76 \pm 22,81 \\
250.40 \pm 24,04 \\
253.22 \pm 29,32 \\
\text { p }>0.05\end{array}$ \\
\hline
\end{tabular}


benzer bir sonuç alınmış, birinci sınıf öğrencilerinin dördüncü siniflara göre analitiklik ve sistematiklik alt boyutlarında daha yüksek puan ortalamasına sahip olduğu bildirilmiştir. Eleştirel düşünmeyi uygulanan eğitim modelinin etkilediği bilinmektedir. İstatistiki bir öneme sahip olmasa da, klasik eğitim müfredatı uygulanan okulların birinci sınıf öğrencilerinin puan ortalamasının dördüncü sinıfların puan ortalamasından daha yüksek; farklı eğitim müfredatı yürüten okulların öğrencilerinde ise tam tersi olarak dördüncü sınıfların puan ortalamasının birinci sınıf ögrencilerinin puan ortalamasından daha yüksek olduğu belirlenmiştir. ${ }^{14}$ Kanbay ve ark.'nın (2011) araştırmasında da yine benzer şekilde KEDEÖ toplam puan ortalaması birinci ve ikinci sınıfta, üçüncü ve dördüncü sınıfa göre daha yüksek bulunmuştur. Probleme dayalı öğrenme yaklaşımının kullanıldığ araştırmada da öğrencilerde KEDEÖ toplam puan ortalamasının orta düzeyde olduğu ve ilerleyen siniflarda artarak son sinıfta en yüksek seviyeye ulaştığ ${ }^{1}$ bulgulanmıştır. ${ }^{17}$ Düşünme biçimleri ve problem çözme yaklaşımlarının kullanıldığ 1 bu modelin uygulanmasının öğrencilerin eleştirel düşünme puanlarını arttırmış olabileceği, klasik anlatım modelinin benimsendiği okullarda ise öğrencinin pasif bilgi alıcı rolünde olması nedeniyle öğrencilerde eleştirel düşünme becerisinin olumsuz etkilendiği düşünülebilir. ${ }^{23}$ Yüksek lisans ve lisans programına devam eden hemşirelik öğrencilerini kapsayan bir başka araştırmada da öğrencilerin eleştirel düşünme düzeyi puan ortalamaları lisansta "düşük" yüksek lisansta "orta" olarak saptanmıştır. Araştırmadan elde edilen bu sonuç, yüksek lisans eğitiminde derslerin tartışmaya dayalı olması, daha fazla araştırmayı, okumayı, bilgileri yorumlamayı gerektirmesi, öğrenci sayısının az olması, öğrencilerin kendi kendine öğrenmeye ve araştırmaya teşvik edilmelerinin fazla olması gibi nedenlerle bu gruptaki öğrencilerin eleştirel düşünme düzeyi daha yüksek bulunmuş olabileceği şeklinde yorumlanmıştır. ${ }^{8}$

Öğrencilerin mezun oldukları okul ile doğruyu arama alt boyutu arasında istatistiksel olarak önemli fark saptanmıştır. Anadolu lisesinden mezun öğrencilerin diğer liselere göre doğruyu arama alt boyutundan daha yüksek puan aldığ 1 belirlenmiştir. Bu sonucun araştırmada yer alan diğer liselere göre Anadolu lisesinde sayısal ağırlıklı derslerin daha fazla olması ve bu liselere giriş puanının daha yüksek olmasından kaynaklandığı düşünülmüştür.

Anne eğitim düzeyi lise ve üzeri olan öğrencilerin açık fikir, analitik düşünce, kendine güven, meraklilik ve KEDEÖ toplam puan ortalamalarında daha yüksek puan aldığı saptand 1 ve anne eğitiminin eleştirel düşüncenin geliştirilmesinde etkili olduğu düşünüldü. Çoğu araştırmada anne eğitim düzeyinin eleştirel düşünme becerisini etkilemediği saptansa da ${ }^{8-10 \text {, }}$ $18,20,23,24$ araştırma sonucumuzu destekler yayınlar da vardır. Örneğin Tümkaya ve Aybek'in (2008) araştırmasında en yüksek eleştirel düşünme puanına, yükseköğretim ve üstü seviyede eğitim alan annelerin çocuklarının sahip oldukları saptanmıştır. Araştırmanın sonucunda bu farkın, annelerin eğitim düzeyinin artmasıyla birlikte çocuk yetiştirme yöntemlerinde daha çok sorgulayıcı ve demokratik bir tutum benimsemiş olmalarından kaynaklanabileceği belirtilmiştir. ${ }^{25}$ Annenin eğitim düzeyinin düşük olması, öğrencinin eleştirel düşünme düzeyinin düşük olmasına neden olduğu, babanın eğitim düzeyinin ise eleştirel düşünme düzeyini etkilemediği saptanmıştır. ${ }^{25}$

Gelir düzeyi ile eleştirel düşünce arasındaki ilişkiye baktığımızda, gelir düzeyini düşük olarak belirten öğrencilerin açık fikir, analitik düşünce, meraklılık ve KEDEÖ toplam puanında gelir düzeyi orta ve yüksek olan öğrencilere göre daha yüksek puan aldıkları saptanmıştır. Bu konuda yapılan diğer araştırma sonuçları değişkendir. Orta ve yüksek gelir seviyesine sahip öğrencilerin, düşük gelir seviyesine sahip öğrencilere göre daha yüksek eleştirel düşünme düzeyine sahip olduğunu ifade eden yayınlar olsa $\mathrm{da}^{19}$ ekonomik durumun eleştirel düşünme düzeyi üzerinde etkili olmadığını belirten yayınlar daha fazladır ${ }^{9,18,20,23-26}$ Yine az sayıda araştırmada da istatistiki öneme sahip olmasa da, araştırmamıza benzer olarak, düşük gelir seviyesine sahip olanların KEDEÖ puan ortalamasının daha yüksek olduğu görülmektedir. ${ }^{18,20}$. Eleştirel düşünceyi zeka, yaşam deneyimi, yaş, yaşanılan ortam, bireyin aldığı eğitim gibi birçok faktörün etkilediği düşünüldüğünde farklı araştırmalarda farklı sonuçların görülmesi beklendik bir sonuç olarak düşünülebilir. Bununla birlikte gelir düzeyi bazı araştırmalarda "algılanan gelir düzeyi" olarak, bazı araştırmalarda ise aylık haneye giren para miktarı olarak yer almıştır. $\mathrm{Bu}$ soru tipindeki farklılığın da sonuçlar arasında değişkenlik oluşturduğu 
düşünülmektedir. Eleştirel düşünme düzeyi yüksek olan öğrencilerde beklentiler daha fazla olduğu için de gelir seviyesi "düşük" olarak işaretlenmiş olabilir.

Araştırmamızda istatistiksel öneme sahip olmasa da, üniversite başarısını çok iyi olarak niteleyen öğrencilerin KEDEÖ'nden en yüksek puanı aldığı belirlendi. Akademik başarının eleştirel düşünme düzeyini $\operatorname{artırdığ~}{ }^{8}$ veya yüksek eleştirel düşünme becerisinin akademik başarıyı da beraberinde getirdiğ $i^{15}$ dolayısıyla akademik başarı ve eleştirel düşünme arasında ilişki olduğu belirtilmektedir. Öğrencilerin akademik ortalamalarına göre eleştirel düşünme eğilim puan ortalamaları arasında istatistiksel olarak anlamlı bir ilişki bulunamayan araştırmalar da vardır. ${ }^{5}$ Sonuçlardaki farklılı̆̆ın kullanılan öğretim metodundan kaynaklanabileceği düşünülmüştür. Konu merkezli, öğreticinin aktif öğrencinin pasif olduğu, öğretimin ezbere dayalı olduğu klasik düz anlatım metodunda akademik başarı iyi olsa da, eleştirel düşünme düzeyi iyi olmayabilir.

Bireyin eleștirel düșünme becerilerine kalıtımsal faktörlerin dışında etki eden önemli faktörlerden birisi de çevresel faktörlerdir. Bireyin eleştirel düşünmesini okul dışında aile ve toplum etkileyebilir. ${ }^{25}$ Aile yapısı ile öğrencilerin akıl yürütme süreçlerine duyduğu güveni yansitan kendine güven ile bilgi edinme ve yeni şeyler öğrenme eğilimini gösteren meraklılık ve KEDEÖ toplam puanında anlamlı fark olduğu saptanmıştır. Parçalanmış aileye sahip öğrencilerin çekirdek ve geniş aileye sahip öğrencilere göre bu alanlarda daha yüksek puan aldıkları belirlenmiştir. Bu sonucun parçalanmış aileye sahip öğrencilerin sorumluluk, kendine güven ve tek başına karar verme durumlarını arttırdığ 1 ve bunun da eleştirel düşünce düzeyi puan ortalamasını olumlu etkilediği düşünüldü.

Öğrencilerin aile tutumu ile eleştirel düşünce puanları arasında istatistiksel olarak anlamlı fark saptanmamıştır. Certel ve ark.'larının (2011) beden eğitimi öğretmenliği öğrencileri ile yaptığı araştırmada da aile tutumunun öğrencilerin eleştirel düşünce düzeyini etkilemediği belirlenmiştir. Palut'un (2008) eğitim fakültesi ögrencilerinde düşünme stilleri ve anne baba tutumları arasındaki ilişkiyi inceleyen araştırmasında çocuklarını kabul edici, ilgili ve psikolojik özerklik sağlayan anne baba tutumları ile eleştirel düşünce stili arasında olumlu ilişki, çocuklarının davranışlarını kontrol edici, kesin ve sert kurallar koyan anne baba tutumları ile eleştirel düşünce stili arasında ise olumsuz bir ilişki saptanmıştır. İskender ve Karadağ'ın (2015) araştırmalarında en düşük eleştirel düşünce puanını otoriter ve reddedici, Tümkaya ve Aybek'in (2008) araştırmasında ise en düşük eleştirel düşünce puanını koruyucu aileye sahip öğrenciler oluştururken, en yüksek eleştirel düşünce puanı demokratik aileye sahip öğrencilerde hesaplanmıştır. ${ }^{14}, 25$ Bununla birlikte mevcut araştırmada en düşük puan ortalamaları olumsuz aile tutumu olarak nitelendirilen aşırı hoşgörülü, otoriter ve reddedici aile yapısına ait öğrencilerde saptanması literatür ile benzer sonuçları göstermektedir. Elde edilen bu bulgular öğrencilerin algıladıkları anne baba tutumları ile ilgilidir. $\mathrm{Bu}$ nedenle en yüksek KEDEÖ puanının aile tutumlarını koruyucu olarak nitelendiren öğrencilerde saptanmas1, öğrencilerin ailelerine koruyuculuk anlamı yüklemesinden kaynaklanmış olabileceğini düşündürmüştür.

\section{SONUC VE ÖNERILER}

Araştırmamızda hemşirelik öğrencilerinin eleştirel düşünme düzeylerinin orta seviyede olduğu saptanmıştır. $\mathrm{Bu}$ bağlamda henüz öğrencilik döneminde iken bu becerileri destekleyen ve geliştiren eğitim programlarının uygulanması önem kazanmaktadır. Öğrencilerin daha aktif katılımlarının sağlanacağı, kendilerini güvende hissedecekleri ders ortamlarının oluşturulması, düşünce süreçlerinin izlenmesi, nitelikli soru sorma ve sorgulamalarının desteklenerek gerekli yönlendirmelerin yapılması ile eleştirel düşüncenin geliştirilmesine destek olunması önemlidir. Öğrencilerin eleştirel düşünme düzeyinin yükseltilebilmesinde eğitici çok önemli bir işleve sahiptir. Hemşirelik öğrencilerinde eleştirel düşünme eğilimlerinin hemşirelik eğitimi ile olan ilişkisi hakkında daha ayrıntılı bilgi edinebilmek için, eğitimden önce ve sonraki verileri kapsayan, uzunlamasina araştırmalar planlanmalıdır.

\section{Yazar Katkısı}

Araştırmanın tasarımı, literatür araştırması, veri analizi ve yazının hazırlanmasi: ŞB

Araştırmanın tasarımı ve yazının hazırlanması: ZKT

\section{KAYNAKLAR}

1. Naber J, Wyatt TH. The effect of reflective writing interventions on the critical thinking 
skills and dispositions of baccalaureate nursing students. Nurse Education Today 2014; 34(1):67-72.

2. Seferoğlu SS, Akbıyık C. Eleştirel düşünme ve öğretimi. H.Ü. Eğitim Fakültesi Dergisi 2006; 30:193-200.

3. Uçan Ö, Taşçı S, Ovayolu N. Eleştirel düşünme ve hemşirelik. Fırat Sağlik Hizmetleri Dergisi 2008; 3(7):17-27.

4. Sullivan EA. Critical thinking in clinical nurse education: application of Paul's model of critical thinking. Nurse Educ Pract 2012; 12(6):322-327.

5. Kanbay Y, Işık E, Aslan Ö. Hemşirelik öğrencilerinin eleştirel düşünme eğilimleri ile akademik başarıları arasındaki ilişkinin incelenmesi. Psikiyatri Hemşireliği Dergisi 2011; 2(3):123-127.

6. Akça KN, Taşçı S. Hemşirelik eğitimi ve eleştirel düşünme. Mersin Üniversitesi Eğitim Fakültesi Dergisi 2009; 5(2):187-195.

7. Dikmen YD, Usta YY. Hemşirelikte eleştirel düşünme. S.D.Ü Sağlık Bilimleri Dergisi 2013; 4(1): 31-38.

8. Öztürk N, Ulusoy $H$. Lisans ve yüksek lisans hemşirelik öğrencilerinin eleştirel düşünme düzeyleri ve eleştirel düşünmeyi etkileyen faktörler. Maltepe Üniversitesi Hemşirelik Bilim ve Sanatı Dergisi 2008; 1(1):15-25.

9. Bulut S. Ertem G. Sevil Ü. Hemşirelik öğrencilerinin eleştirel düşünme düzeylerinin incelenmesi. DEUHYO ED 2009; (2):27-38.

10.Atay S, Ekim E, Gökkaya S, Sağım E. Sağlık yüksekokulu öğrencilerinin eleştirel düşünme düzeyleri. Hacettepe Üniversitesi Sağlık Bilimleri Fakültesi Hemşirelik Dergisi 2009; 39-46.

11.Kong LN, Qin B, Zhou Y, Moub S, Gao MH. The effectiveness of problem-based learning on development of nursing students' critical thinking: a systematic review and metaanalysis. Int J Nurs Stud 2014; 51(3):458-469. 12.Lin CC, Han CY, Pan IJ, Chen LC. The teaching learning approach and critical thinking development: a qualitative exploration of Taiwanese nursing students. J Prof Nurs 2015; 31(2):149-57.

13.Pitt V, Powis D, Levett-Jones T, Hunter S. The influence of critical thinking skills on performance and progression in a preregistration nursing program. Nurse Education Today 2015; 35(1):125-131.

14.Şenturan L, Alpar ŞE. Hemşirelik öğrencilerinde eleştirel düşünme. C.Ü
Hemsirelik Yüksekokulu Dergisi 2008; 12(1): 22-30.

15.Kökdemir D. Belirsizlik durumlarında karar verme ve problem çözme. [Doktora Tezi]. Ankara Üniversitesi Sosyal Bilimler Enstitüsü, Ankara, 2003.

16. Ergin B. Tartışma yöntemine dayalı etkinliklerin sınıf öğretmen adaylarının genetiği değiştirilmiş (GD) besinlere ilişkin risk algılarına ve eleştirel düşünme eğilimlerine etkisinin incelenmesi. [Yüksek Lisans Tezi]. Adıyaman Üniversitesi Fen Bilimleri Enstitüsü, Adiyaman, 2013.

17.Küçükgüçlü Ö, Kanbay Y. Hemşirelik ögrencilerinin eleştirel düşünme eğilimleri ile klinik başarıları arasındaki ilişkinin incelenmesi. Anadolu Hemşirelik ve Sağlik Bilimleri Dergisi 2011; 14(3):21-25.

18.Zaybak A, Khorshid L. Ege Üniversitesi Hemşirelik Yüksekokulu öğrencilerinin eleştirel düşünme düzeylerinin incelenmesi. Ege Üniversitesi Hemşirelik Yüksek Okulu Dergisi 2006; 22(2):137-146.

19. Dirimeşe E, Dicle A. Hemşirelerin ve hemşirelik öğrencilerinin eleştirel düşünme eğilimlerinin değerlendirilmesi. Anadolu Hemşirelik ve Sağlık Bilimleri Dergisi 2012; 15(2):89-98.

20. Özdelikara A, Bingöl G, Görgen Ö. Hemşirelik öğrencilerinin eleştirel düşünme eğilimleri ve bunu etkileyen faktörler. İ.Ü.F.N. Hemşirelik Dergisi 2012; 20(3):219-226.

21. Raymond $\mathrm{Cl}$, Profetto-Mcgrath J. Nurse Educators' critical thinking: Reflection and measurement. Nurse Educ Pract 2005; 5(4):209-217.

22. Wangensteen S, Johansson IS, Björkström ME, Nordström G. Critical thinking dispositions among newly graduated nurses. J Adv Nurs. 2010;66(10):2170-81.

23. Özdemir SM. Üniversite öğrencilerinin eleştirel düşünme becerilerinin çeşitli değişkenler açısından değerlendirilmesi. Türk Eğitim Bilimleri Dergisi 2005; 3(3): 1-17.

24. Çınar N, Akduran F, Aşkın M, Altınkaynak S. Hemşirelik bölümü öğrencilerinin eleştirel düşünme düzeyi ve eleştirel düşünmelerini etkileyen faktörler. Türkiye Klinikleri Hemşirelik Bilimleri Dergisi 2012; 4(1):8-14.

25. Tümkaya S, Aybek B. Üniversite öğrencilerinin eleştirel düşünme eğilimlerinin sosyo-demografik özellikler açısından incelenmesi. Ç.Ü. Sosyal Bilimler Enstitüsü Dergisi 2008; 17(2):387-340. 
26. Arslan GG, Demir Y, Eşer İ, Khorshid L. Hemşirelerde eleştirel düşünme eğilimini etkileyen etmenlerin incelenmesi. Atatürk Üniversitesi Hemşirelik Yüksekokulu Dergisi 2009; 12:72-80.

27. Certel Z. Çatıkkaş F. Yalçınkaya M. Beden eğitimi öğretmen adaylarının duygusal zeka ile eleştirel düşünme eğilimlerinin incelenmesi. Selçuk Üniversitesi Beden Eğitimi Ve Spor Bilim Dergisi 2011;13(1):74-81.

28. Palut B. Düşünme stilleri ve anne-baba tutumları arasındaki ilişki. Dokuz Eylül Üniversitesi Buca Eğitim Fakültesi Dergisi 2008; 24:1-11.

29. İskender MD, Karadağ A. Hemşirelik son sınıf öğrencilerinin eleştirel düşünme düzeylerinin belirlenmesi. DEUHFED 2015; 8(1), 3-11. 